\title{
Tomasz Góra
}

School of Economics, Law and Medical Sciences, Kielce

gora.tomasz@wp.eu

ORCID: 0000-0002-5637-2060

\section{Action in a case ended with an administrative decision}

\begin{abstract}
The article deals with the issue of administrative procedural law and civil court proceedings. The author describes a special right of the parties to administrative proceedings, which is the right to bring an action against an administrative decision, and attempts to analyse the action in relation to the administrative decision against the control of common courts against individual acts of public administration. This analysis is carried out in the light of the provisions of the Code of Civil Procedure, as well as on the legal grounds for bringing actions against administrative decisions. The article was enriched with a number of judgments of common and administrative courts. At the end of the article, the author formulates de lege ferenda conclusions.
\end{abstract}

\section{KEYWORDS}

action, administrative decision, party, common court of law, public administration body

\section{Introduction}

The motivation to write this article stemmed from: 1) little interest in the subject matter of the doctrine of administrative law, 2) the need to carry out a dogmatic and legal analysis of issues covering the special right of the parties to administrative proceedings to bring an action concerning an administrative decision.

The issue of action in a case ended with an administrative decision is part of the broader subject area of the control of administrative decisions by the common courts.

The literature strongly emphasises the view that the control of administrative decisions can be exercised by the common courts only if this results from a clear statutory mandate. ${ }^{1}$

1 J. Borkowski, Sad powszechny w kontroli administracji publicznej w sprawach indywidualnych, in: J. Borkowski, B. Adamiak, Postępowanie administracyjne i sq̨dowoadministracyjne, Warszawa 2019, https://sip.lex.pl/\#/monograph/369 460336/95?keyword=barbara\%20adamiak\&tocHit=1\&cm=SFIRST. Accessed 02.12.2020; J. Litwin, Problematyka sądownictwa administracyjnego, NP 1956, no. 1, pp. 4-5; J. Jagielski, Kontrola administracji publicznej, Warszawa 2006, pp. 135-137. 
This problem has been recognised by the Supreme Court. The justification of the Supreme Court's resolution (7z) of 23 November $1959^{2}$ indicated: "In the State, strictly defined and separately formed state bodies are appointed to perform the functions of the judiciary and state administration, and the possible opportunity to influence of the activity in one area on the activity in another is limited to certain situations, especially those provided for in the Act. In this state of affairs, the courts may, by their rulings, only challenge administrative acts if a specific provision of the law allows it. In particular, a civil relationship cannot be used to challenge a decision issued by a state administration body by means of a judgment of a common court, as this would create a specific means of overriding an administrative decision by means of a judgment of a common court, that is, interference by the civil judiciary in a sphere reserved for state administration. An action formulated in this way should be characterised according to its actual content, that is to say, as a complaint against an administrative decision for which no judicial process is available".

Against the background of the current legislation, the legal science formulates two main categories, in which common courts may interfere in the activities of public administration, expressed in the form of administrative decisions.

The first will be a situation where "the court, by virtue of an explicit statutory provision, is called upon to resolve a case in which an administrative decision has already been made (temporary inadmissibility of the judicial process)". The second will be a situation in which "a court by virtue of an express statutory provision is appointed to hear an appeal or other action against an administrative decision (a common court as an appeal body)".

In this article, the author will focus primarily on the first category, i.e., temporary inadmissibility of the judicial process. However, in order to properly understand the issue and to identify similarities and differences between these two categories, it will become necessary to analyse the second category too.

Temporary inadmissibility of the judicial process concerns a specific procedure for the assertion of claims. The case is considered by one administrative instance and a party dissatisfied with the decision may file a claim with the civil court, which will hear the case anew. The court has no power to change or revoke an administrative decision or to declare it illegal, because it would need a special legal basis for such actions. "The courts, when considering these cases, do not take into account the legality of a previous administrative decisions; on the contrary, the premise of the rule of law seems to play a major role here. In many cases, the courts, in the exercise of their judicial functions, must assess the legality of specific administrative actions". 4

In turn, the role of the common court as an appeal body against administrative decisions (the so-called hybrid procedure) is different and has a different effect on an administrative decision than in the case of a temporary inadmissibility of the judicial process. The

2 Resolution of the Supreme Court (7z) of 23.11.1959, case file I CO 20/59, OSNCK 1960, no. 2, item 32. https://sip.lex. $\mathrm{pl} /$ ?_ga=2.105606785.388146383.1606892008-848456491.1539524780\#/jurisprudence/520209364/1 ?directHit=true \&directHitQuery=I\%20CO\%2020 2F59. Accessed 02.12.2020.

3 J. Borkowski, op. cit.

4 J. Łętowski, Sądy powszechne i praworządność w administracji, Wrocław 1967, p. 23. 
specificity of the common court as an appeal body against administrative decisions can be illustrated by two types of proceedings: 1) on appeals against decisions in the area of cash benefits in social security matters (pensions, annuities, allowances, etc.), and 2) on appeals against decisions of the President of the Office of Competition and Consumer Protection. In both cases, the courts have reform and cassation competence over administrative decisions. They can change decisions in whole or in part and decide on the substance of the case. This is a clear difference between the competences of the administrative courts, which are primarily called upon to review administrative decisions, and the common courts. As a rule, administrative courts have cassation competences and as indicated above, common courts have broader competences than administrative decisions.

When transferring the analysis of the issue of action in a case ended with an administrative decision onto the ground of administrative proceedings, one should start by stating that pursuant to Article 107(1)(9) of the Act of 14 June 1960 on the Code of Administrative Procedure ${ }^{5}$ the Decision contains: in the case of a decision against which an action may be brought before a common court, an objection to the decision or a complaint to the administrative court - a notice on the admissibility of bringing the action, objection to the decision or complaint and the amount of the fee for the action or entry of the complaint or objection to the decision, if they are permanent in nature, or the basis for calculating the fee or entry of a relative nature, as well as the possibility for the party to apply for exemption from costs or for the right to assistance.

The notice referred to in the above-mentioned provision is mandatory. An administrative body competent to issue an administrative decision is obliged to include an appropriate notice on the admissibility of bringing an action before a common court. The authority is obliged to determine, based on the provisions of the proceedings outside the CAP, from which decision an entity is entitled to bring an action.

The lack of an advisory notice cannot be qualified as an erroneous advisory notice (Article 112 of the CAP). In the case of an erroneous advisory notice, the notice is included in the decision, it has only the defective content. In the absence of an advisory notice, the authority does not inform the party at all about the available legal remedies. Acceptance of the admissibility of applying Article 112 of the CAP to a situation where there is no notice of appeal would result in a party being able to lodge an effective appeal at any time, and a decision not containing such a notice could not become final. This is unacceptable in the light of the principle of permanence of final decisions expressed in Article 16 of the CAP. ${ }^{6}$

Pursuant to Article 111(1) of the CAP, a party may, within fourteen days from the date of delivery or announcement of the decision, demand its supplementation as to the ruling or as to the right of appeal, bring an action before a common court or a complaint before an administrative court or request a correction of an advisory notice contained in the decision. $\S 2$ of the above-mentioned article states: "If the decision referred to in $\S 1 b^{7}$ has been issued,

5 Dz.U. (Journal of Laws) of 2020, item 256, as amended, hereinafter referred to as the "CAP".

6 Judgment of the Voivodship Administrative Court in Warszawa of 14 February 2012, case file I SA/Wa 2369/11, LEX no. 1121563 .

7 Supplementation or refusal to supplement the decision shall take the form of an order. 
the time limit for a party to file an appeal, action or complaint shall run from the date of its delivery or announcement. No appeal, action or complaint to the administrative court shall be made against the order to supplement the decision (as to the decision or as to the right of appeal, bringing an action before a common court or a complaint to an administrative court)" 8

Article 112 of the CAP reads as follows: "An erroneous advisory notice in the decision regarding the right of appeal or the consequences of renouncing an appeal or bringing an action before a common court or a complaint before an administrative court shall not be prejudicial to a party that has complied with it".

Lack of an advisory notice is treated as erroneous advisory notice within the meaning of Article 112 of the CAP. The provision of Article 112 of the CAP provides that erroneous advisory notice in the decision as to the right of appeal or bringing an action before a common court or a complaint before an administrative court shall not be prejudicial to a party that has complied with it. ${ }^{9}$

Pursuant to the content of Article 112 of the CAP, an erroneous advisory notice in the decision as to the right of appeal or to bring an action before a common court or a complaint before an administrative court shall not be prejudicial to a party that has complied with it. ${ }^{10}$

It follows from the above considerations that an advisory notice on the admissibility of an action against an administrative decision before a common court is a mandatory element of those administrative decisions from which such a measure is entitled. The authority is obliged to include this notice. Failure to include an advisory notice in the decision should be qualified as an erroneous advisory notice and shall not be prejudicial to a party that has complied with it. However, there is no uniform position of administrative court judicature here.

\section{Civil law regulations: A procedural approach}

In Article 1 of the Code of Civil Procedure, ${ }^{11}$ the legislator defined the term "civil case". The Code of Civil Procedure regulates court proceedings in matters of civil, family, and guardianship law and labour law, as well as in matters of social security and other cases to which the provisions of this Code apply by virtue of specific acts (civil cases).

The definition of a civil case is important for the admissibility of legal proceedings before a common court or a civil court. Traditionally, it distinguishes the concept of a civil case based on substantial premises and a civil case in the formal sense. The substantive criterion is not sufficient to establish the admissibility of legal proceedings before the common civil

8 Similar ruling of the Supreme Administrative Court of 10 April 2008, case file I OSK 875/07, LEX no. 505244.

9 Judgment of the Voivodship Administrative Court in Gdańsk of 26 September 2019, case file II SA/Gd 234/19, LEX no. 2726395 .

10 Judgment of the Supreme Administrative Court of 28 January 2020, case file II OSK 689/18, LEX no. 2798771.

11 Act of 17 November 1964 on the Code of Civil Procedure, Dz.U. (Journal of Laws) of 2019, item 1460, as amended, hereinafter referred to as the "CCP". 
court, since it follows from Article 2 that civil cases sometimes fall within the jurisdiction of special courts. The identifying feature of a case, which is a civil case by its very nature, is the guarantee of legal protection of a legal status or legal relationship of an equivalent and comparable nature. ${ }^{12}$

Civil cases in the formal sense are those for which specific provisions provide for civil court proceedings, even though they do not have elements relevant to a civil case in the substantive sense. Such cases include, first of all, social security cases explicitly mentioned in Article 1 (judgments of the Supreme Court of 1 September 2010, case file III UK 15/10, LEX no. 667499; of 22 October 2013, case file III UK 154/12, LEX no. 1463908), as well as regulatory cases, the procedure for the examination of which is provided for in Articles 479(46)-479(78). Moreover, they are listed in non-codex regulations, e.g. Article 36 of the Law on Civil Status Records and Article 5 of the Decree of 7 July 1945 on the Reconstitution of Diplomas and Certificates of Completion of Studies, Dz.U. (Journal of Laws), no. 27, item 164 , as amended. ${ }^{13}$

It should be considered that proceedings brought against an administrative decision constitute a civil case in a formal sense. The status of these proceedings falls within the definition of a civil case and is derived from specific laws.

Pursuant to Article 2(1) of the CCP, common courts are appointed to hear civil cases, unless such cases fall within the jurisdiction of special courts, and the Supreme Court. Pursuant to Article 16(1) of the CCP, district courts adjudicate on all cases except for those for which the jurisdiction of regional courts is reserved. Furthermore, pursuant to the provisions of the CCP, only the courts referred to in Articles 479(28) et seq., 479(46), 479(57) et seq., 479(60) and 479(79) of the CCP shall have jurisdiction over appeals against administrative decisions of certain public administrations. The provisions mentioned above refer to "an appeal" against the administrative decision and not to actions in relation to the administrative decision. It is a separate form of questioning administrative decisions, which transfers the administrative dispute to the judicial level (civil law level).

A dispute over jurisdiction also includes a dispute over the determination of the appropriate course of action in cases of appeals or action in a case ended with an administrative decision. This issue has been dealt with by the Supreme Court and has been expressed in Resolutions III CZP 30/01, ${ }^{14}$ III CZP 77/09, ${ }^{15}$ and III CZP 116/08. ${ }^{16}$ It follows from the above

12 M. Manowska, Article 1, in: Kodeks postępowania cywilnego. Komentarz, Vol. 1, System Informacji Prawnej LEX, https://sip.lex.pl/\#/commentary/587826880/624320. Accessed 19.07.2020.

13 Ibidem.

14 The court proceedings to adjudge a fee for an increase in the value of the real estate, determined in an administrative decision issued pursuant to Article 36(3) and (9) of the Act of 7 July 1994 on Spatial Development, consolidated text: Dz.U. (Journal of Laws) of 1999, no. 15, item 139, as amended, are inadmissible, LEX no. 47598.

15 The court proceedings in the case of reimbursement of expenses incurred alternatively by the municipality in the event of failure to pay for the stay in a residential care home by persons referred to in Article 61(2)(2) of the Act of 12 March 2004 on Social Assistance, consolidated text: Dz.U. (Journal of Laws) of 2008, no. 115, item 728, as amended, are inadmissible, LEX no. 522992.

16 The court proceedings in the case of the municipality's claim for payment of the amount of the additional annual fee established by the decision taken pursuant to Article 63 of the Act of 21 August 1997 on Real Estate Management, consolidated text: Dz.U. Journal of Laws of 2004 no. 261, item 2603, as amended, are inadmissible, LEX no. 468638. 
Resolutions that the judicial route from the administrative decisions was questionable and its inadmissibility had to be judged by the Supreme Court.

The question of whether a civil court is bound by the findings of a public administration authority as to the basis on which an administrative decision has actually been made is also a matter of concern in the judiciary. In the above case, we can point to the decisions of the Supreme Court. In the absence of a provision analogous to Article 11 of the CCP (binding of a civil court by a criminal conviction) there are no grounds for stating that the court, when examining a case in civil proceedings, is obliged to consider the facts established by an administrative authority and adopted as the basis for its decision. ${ }^{17}$

Pursuant to Article $16 \$ 1$ of the CCP, ${ }^{18}$ decisions which are not subject to appeal or an application for a review are final. Such decisions may be revoked or amended, declared invalid and proceedings may be resumed only in cases provided for in the Code or in specific acts.

It cannot be deduced from the wording of the said provision that the binding nature of a court in civil proceedings by an administrative decision precludes the possibility of making a different assessment of the facts on which this decision is based or of applying for legal effects different from those for which administrative rulings are provided. The above was pointed out in the resolution of seven judges of the Supreme Court of 9 October 2007, case file III CZP 46/07, pointing out that "the power of the court to determine objective events constituting the factual basis of the decision itself cannot, in the light of Article 233 of the CCP, be called into question. Possible limitations in this respect would have to result from statutory regulations, as is the case of a criminal conviction (Article 11 of the CCP). The cognizance of the court cannot be restricted as regards the possibility of deriving further civil law effects from facts assessed by an administrative authority in a situation where the administrative decision does not concern such further effects". ${ }^{19}$

In another judgment, the Supreme Court referred to the effects of the administrative decision and its evaluation by the court. In civil proceedings, the court is not entitled to question the correctness and effects of an administrative decision, even if in its assessment it is defective, except for decisions affected by the so-called absolute nullity (non-existent decisions), i.e. issued by an unauthorised authority or without observing any provisions of the proceedings, or without a substantive and legal basis, where "lack of a substantive and legal basis" does not mean a substantive defectiveness, but only the lack of substantive and legal regulation of the subject matter which the administrative authority ruled on in the decision. ${ }^{20}$

The Supreme Court, in its judgment of 27 February 2019, held that the civil court is bound by the established legal status which is the basis for issuing an administrative decision (legal effect of the decision). In civil proceedings, the court is bound by an administrative decision of significance for the settlement of a civil case. Binding means that the court

17 Judgment of the Supreme Court of 9 October 2019, case file I NSK 59/18, LEX no. 2729332.

18 Act of 14 June 1960 on the Code of Administrative Procedure, Dz.U. (Journal of Laws) of 2018, item 2096, as amended, hereinafter referred to as the "CAP".

19 From justification of the judgment of the Supreme Court of 9 October 2019, case file I NSK 59/18, LEX no. 2729332.

20 Judgment of the Supreme Court of 19 June 2019, case file II CSK 288/18, LEX no. 2684159. 
has to consider the legal status as shaped or established in the decision. In this respect, the court is not entitled to make a different assessment of the legal consequences of certain facts constituting the basis for the decision. ${ }^{21}$

In yet another judgment, the Supreme Court analysed the question of challenging final administrative decisions by a common court. The common court has no power to question final administrative decisions, and even if these decisions are affected by defects, it cannot question their substance. An exception to this rule can only be made if the decision appears to be non-existent or is absolutely null and void, i.e., it undermines the very essence of the administrative act, which is an administrative decision (e.g. not being issued by an administrative authority). Any undermining of administrative decisions falls within the scope of the legal and administrative jurisdiction. ${ }^{22}$

The following conclusions can be drawn from the above-mentioned rulings: 1) the civil court is not bound by the factual findings being the basis for issuing an administrative decision, 2) the civil court is bound by the legal status (legal effect) established in administrative proceedings as the basis for issuing an administrative decision, 3) the common court is not entitled to challenge final administrative decisions, even if they are affected by legal defects. The court should adjudicate in this respect within the scope of competence and jurisdiction.

An action in a case ended with an administrative decision as to its form shall not constitute a separate case from a classic action, as defined by the provisions of Article 187 of the CCP, which states: $\$ 1$. The claim should satisfy the terms of the pleading and should also contain: 1) a precisely defined claim, and in cases involving property rights also an indication of the value of the subject of the dispute, unless the subject of the case is a fixed sum of money, 2) an indication of the date on which the claim is due in cases involving an award of a claim, 3) an indication of the facts on which the claimant bases his/her claim and, where necessary, also justifying the jurisdiction of the court, 4) information whether the parties made a mediation attempt or any other out-of-court settlement of the dispute and, if no such attempt has been made, an explanation of the reasons for not making it. \$2. The statement of claim may contain motions for securing the claim, making the judgment immediately enforceable and conducting a hearing in the plaintiff's absence, as well as motions for preparing a hearing, and in particular: 1) summoning witnesses and experts indicated by the claimant to a hearing, 2) carrying out an inspection, 3) ordering the defendant to deliver at a hearing a document in his/her possession which is necessary to carry out evidence or the subject of the inspection, 4) requesting evidence held at courts, offices or third parties, together with the fact that the party cannot obtain it by itself.

21 Judgment of the Supreme Court of 27 February 2019, case file I NSK 17/18, LEX no. 2643232. Similarly, in the judgment of the Supreme Court of 18 November 2016, case file I CSK 759/15, and in the resolution of the Supreme Court of 9 October 2007, case file III CZP 46/07 "On the reconciliation of the legal status of real estate - disclosed in the Land and Mortgage Register based on the final administrative decision issued pursuant to Article 18 (1) in connection with Article 5 (1) of the Act of 10 May 1990 - Provisions introducing the Act on local government and the Act on local government employees, Dz.U. (Journal of Laws), no. 32, item 191, as amended - with the actual legal status, the court is bound by such decision". LEX no. 298665.

22 Judgment of the Supreme Court of 10 August 2017, case file I CSK 30/17, LEX no. 2352155. 


\section{Legal grounds for bringing an action against administrative decisions}

After a dogmatic analysis of the legal regulations and whether there are any legal regulations concerning the grounds for bringing actions against administrative decisions, it should be stated that the legislator provides for such a form of "challenging" the decision as an exception to the general rule of appeals against administrative decisions to a higher-level body (within the meaning of the CAP). This issue is of small interest to the legislator. It should be noted, however, that the legislator has introduced, exceptionally, the right for the parties to bring an action in some cases. As examples of legal regulations, the following grounds for bringing actions against administrative decisions can be indicated:

1) Article 131(2) of the Act of 27 April 2001 - the Environmental Protection Law ${ }^{23}$ provides: A party dissatisfied with the compensation granted may, within 30 days from the date of service of the decision referred to in paragraph 1, file an action with a common court. The court shall also have jurisdiction if the competent authority does not issue a decision within 3 months of the date of the injured party's request. In accordance with paragraph 1 of the afore-mentioned Article 131, in the event of a limitation on the use of the property referred to in Article 130(1), the competent district governor shall, at the request of the injured party, fix, by decision, the amount of compensation; the decision shall be uncontested.

There is no doubt that the decision referred to in Art. 131 of the EPL is an administrative decision within the meaning of the CAP and is issued by a public administration body a district governor (starosta). It follows from the content of paragraph 1 of Article 131 of the EPL that the decision is not subject to appeal. Non contestability of this decision concerns the administrative procedure and the right of appeal. By the way, it is important to note the legislative incorrectness of the legislator, which uses the term "not contestable". A rational legislator is required to create the rules that are part of the legal system correctly and consistently. A better formulation would be, for example, that "the decision is not subject to appeal". In Article 131(2) of the EPL, the legislator introduces the right for a party to bring an action before a common court. This is clearly indicated by the wording of this provision. In this case, the legislator limited the right of a party only to bring an action, depriving it of the possibility of appeal in the course of the administrative proceedings. Why did he do this? It seems that the answer to this question should be sought in the subject and scope of the action. In accordance with Article 131(2) of the EPL "the party dissatisfied with the compensation granted...". Generally speaking, the issue of compensations remains within the scope of the jurisdiction of the common courts, and this may be a factor determining whether the legislator has transferred this category of case to be examined by the common court, and not by a public administration body.

In the course of the proceedings brought by the claim, the court in civil proceedings, pursuant to Article 131(1) of the EPL, shall have the power to examine the legitimacy of the compensation granted by the administrative authority, and not only to check the correctness of its determination. ${ }^{24}$

23 Dz.U. (Journal of Laws) of 2020, item 1219, as amended, hereinafter referred to as the "EP".

24 Judgment of the Voivodship Administrative Court in Białystok of 6 June 2013, case file I Aca 107/13, LEX no. 1335594. 
In view of the content of Article 131 of the EPL adopted in this way, a number of doubts arise in connection with the relationship between administrative proceedings and court proceedings. This is pointed out by K. Gruszecki, ${ }^{25}$ who indicates the following problems:

- When claims can be pursued before a court in case of parallel administrative proceedings. The author assumes that the condition is that an administrative decision (not contestable) or no decision is issued within 3 months of the injured party's request. 26

- The question of the form of possible termination of the administrative proceedings if the dissatisfied party, after three months to settle the matter, has successfully brought an action before a common court. The author points to the discontinuance of proceedings pursuant to Article $105 \$ 1$ of the CAP.

- Is it possible for an administrative authority to issue a decision terminating the proceedings after the expiry of the time-limit set out in Article 131(2) of the EPL in a situation where the party has not brought an action before a common court? According to the author, there are no contraindications to issue, after the lapse of this period, a decision deciding on claims for restriction of the right to use the real estate (with the reservation that after the lapse of this period no action has been brought before a court).

- Will there be a right to take legal proceedings if an administrative authority makes any decisions, or only for a specific category of decisions?

- What is the relationship between the decision awarding compensation and a possible judgment of a common court terminating proceedings in this case?

I share all of the author's doubts, and without referring to them in detail, I find that they point to an unfortunate interface between administrative law and civil law, which, in the absence of precise regulations, gives rise to great interpretative doubts. For the parties to the proceedings, it also means a lack of a sense of legal accuracy and transparency. There is no doubt that the combination of two different branches of law, even from the procedural point of view, raises concerns about the uniformity and completeness of this procedure from the point of view of the party (the claimant).

2) Article $37 \mathrm{~h}(2)$ of the Act of 27 March 2003 on Spatial Planning and Development ${ }^{27}$ states: A party dissatisfied with the compensation granted may, within 30 days of the date of delivery of the decision referred to in paragraph 1, file an action with a common court. The court shall also be entitled to take legal action if the competent authority fails to issue a decision within 3 months of the date of the injured party's request. Pursuant to Article $37 \mathrm{~h}(1)$ of the SPD, in the event of a limitation of the use of the property as a result of the establishment of regulations referred to in Article $37 \mathrm{~g}(2)(4)$, at the request of the injured party, the competent district governor (starosta) shall determine, by decision, the amount of compensation. The decision of the starosta is not subject to appeal.

25 K. Gruszecki. Article 131, in: Prawo ochrony środowiska. Komentarz, Wolters Kluwer Polska, https://sip.lex.pl/\#/commentary/587291860/590794. Accessed 22.07.2020.

26 See the judgment of the Voivodship Administrative Court in Warszawa of 29 October 2004, case file IV SA 2007/03, LEX no. 164442.

27 Dz.U. (Journal of Laws) of 2020, item 293, as amended, hereinafter referred to as the "SPD". 
The above regulation is to some extent similar to the content of Article 131 of the EPL. Therefore, the comments made in point 1 will partly apply also here.

The administrative procedure for compensation is one-stage. It is not possible to appeal the decision of the district governor (starosta) to a higher level (second instance) body. Issuing a decision that is unsatisfactory to the party (the applicant) or a lack of such a decision within 3 months from the date of submitting the application (according to the authors from the date of submitting the application to the authority), entitles the party (the applicant) to bring an action before a common court. Submitting a claim triggers new court proceeding, which is not a continuation of the administrative proceedings that ended with a decision with which the applicant is not satisfied. ${ }^{28}$

3) Article 14(6) of the Act of 29 June 2011 on Preparing for and Performing Investments Involving Nuclear Power Facilities and Accompanying Investments ${ }^{29}$ provides that a party dissatisfied with the compensation granted to it may bring an action before the common court within 30 days from the date of delivery of the decision on compensation. The bringing of the action shall not suspend the execution of the decision. Pursuant to Article $14^{30}(5)$ of the said Act, the decision on compensation is issued by the voivode within one month, at the request of the owner or perpetual usufructuary of the real estate, or a person who has a limited right in rem to the real estate submitted not later than within 2 months from the day on which the decision on the indication of the investment location or the permit to enter the real estate expired. The decision is not subject to appeal.

This regulation is also similar in nature to those discussed earlier.

4) Article 46e(4) of the Act of 13 October 1995 on Hunting Law. ${ }^{31}$ The owner or holder of agricultural land on which the damage referred to in Article 46(1) has occurred, as well as the lessee or manager of the hunting district dissatisfied with the decision referred to in paragraph 1, may, within three months from the date of its delivery, bring an action before

28 A. Plucińska-Filipowicz, A. Kosicki, Art. 37(h), in: Ustawa o planowaniu i zagospodarowaniu przestrzennym. Komentarz aktualizowany, Legal Information System LEX, https://sip.lex.pl/\#/commentary/587754911/599324. Accessed 22.07.2020.

29 Dz.U. (Journal of Laws) of 2018, item 1537, as amended.

30 Article 14 of the Act of 29 June 2011 on Preparing for and Performing Investments Involving Nuclear Power Facilities and Accompanying Investments. 1) The investor, after completion of measurements, research or other works referred to in Article 11 paragraph 1, is obliged to restore the real estate to its previous state. If the restoration of the real estate to its previous state is not possible or causes excessive difficulties or costs, the owners, perpetual usufructuaries and persons with limited rights in rem are entitled to compensation from the investor. 2) The compensation should correspond to the value of the damage suffered. If the value of the real estate decreases because of these events, the compensation shall be increased by the amount corresponding to that decrease. 3) For determining the amount of compensation, Articles 130, 134 and 135 of the Act of 21 August 1997 on Real Estate Management, Dz.U. (Journal of Laws) of 2018, items 121, 50, 650, 1000 and 1089, shall apply accordingly. 4) In the case referred to in Article 11(1) (1), owners and perpetual usufructuaries and persons who have limited rights in rem to real estate are also entitled to compensation for the effects referred to in Article 6(4)(2) and (3). 5) The decision on compensation shall be issued by the voivode within one month, at the request of the owner or perpetual usufructuary of the real estate or a person who has a limited right in rem to the real estate submitted not later than within 2 months from the day on which the decision on the location of the investment project or the permit to enter the real estate expired. The decision is not subject to appeal. 6) A party dissatisfied with the compensation granted to it may bring an action before a common court within 30 days from the date of service of the decision on compensation. Lodging an action does not suspend the execution of the decision.

31 Dz.U. (Journal of Laws) of 2020, item 67, as amended, hereinafter referred to as the "Hunting Law". 
the court competent for the place where the damage occurred. Pursuant to Article 46e(1) to (3) of the Hunting Law 1) The District Manager of the State Forests National Forest Holding, competent for the place where the damage occurs, shall determine the amount of compensation by way of a decision, taking into account in particular the arrangements contained in the protocols referred to in Article 46a(4), Article 46c(5) and Article 46d(8). The opinion of the representative of the Agricultural Chamber referred to in Article 46d(9) shall not be binding. 2) The decision referred to in paragraph 1 shall be issued within 14 days of receipt of the protocols referred to in paragraph 1 and shall be final. 3) The payment of the compensation referred to in paragraph 1 shall be made from the funds of the lessee or manager of a hunting region, not later than within 30 days from the date of delivery of the decision referred to in paragraph 1 .

The subject of the action is also compensation for the damage caused. Against the background of the analysis of the above-mentioned provisions of the Hunting Law, apart from the doubts already raised, due to the contact between the administrative proceedings and civil proceedings, it can also be pointed out that the decision establishing the compensation and its amount was being questioned incorrectly. The parties wrongly directed complaints to administrative courts, which were correctly rejected by those courts. The courts did not recognise their jurisdiction to hear cases. This is indicated by the decisions of voivodship administrative courts. ${ }^{32}$

In one of the justifications for the Voivodship Administrative Court's ${ }^{33}$ decision we can read: The complaint shall be rejected, as the case does not fall within the jurisdiction of the administrative court.

Pursuant to the content of Article $3 \$ 1$ of the Act of 30 August 2002 on the Law on Proceedings before Administrative Courts, Dz.U. (Journal of Laws) of 2019, item 2325, as amended, hereinafter referred to as the "LPAC", administrative courts exercise control over the activities of public administration and apply the measures specified in the Act. The subject of control carried out by the administrative courts is primarily the forms of authoritative and unilateral activity of public administration bodies listed in Article $3 \$ 2$. This control includes, inter alia, adjudicating on complaints against administrative decisions, decisions issued in administrative proceedings, in enforcement and security proceedings, and other acts or activities in the field of public administration referred to in Article $3 \$ 2$ point 4 of the LPAC. In the case under consideration, the District Manager of the Forest Inspectorate K. established, pursuant to Article 46e of the Act of 13 October 1995 on the Hunting Law, Dz.U. (Journal of Laws) of 2018, item 2033, as amended, the amount of compensation due to the applicant A. M. for hunting damage caused by wild boars in agricultural crops. Pursuant to this regulation, the District Manager of the State Forests National Forest Holding responsible for the place where the damage occurs shall deter-

32 Resolution of the Voivodship Administrative Court in Białystok of 12 March 2020, case file II SA/Bk 157/20, LEX no. 2830010. Resolution of the Voivodship Administrative Court in Szczecin of 18 February 2020, case file II Sa/Sz 52/20, LEX no. 2783924. Resolution of the Voivodship Administrative Court in Gdańsk of 30 December 2019, case file III SA/Gd 789/19, LEX no. 2759896.

33 Resolution of the Voivodship Administrative Court in Białystok of 12 March 2020, case file II SA/Bk 157/20, LEX no. 2830010 . 
mine the amount of compensation by way of a decision, taking into account, in particular, the arrangements contained in the protocols referred to in Article 46a(4), Article 46c(5) and Article 46d(8). However, pursuant to Article 46e(4) of the Act, the owner or holder of agricultural land on which the damage referred to in Article 46(1) has occurred, as well as the lessee or manager of a hunting region dissatisfied with the decision referred to in paragraph 1, may, within three months of the date of its delivery, bring an action before the court having jurisdiction over the place where the damage occurred. It follows from the above that the competent court for this case is the common court with jurisdiction over the place where the damage occurred (see judgment of the Voivodship Administrative Court in Szczecin of 8 January 2020, case file II SA/Sz 1172/19; judgment of VAC in Warszawa of 17 February 2020, case file IV SA/Wa 2772/19).

Due to the civil law nature of the dispute in this case, the court, pursuant to Article 58(1) (1) of the LPAC, decided to reject the complaint.

5) Article 73(2d) and (2e) of the Act of 21 August 1997 on Real Estate Management. ${ }^{34}$ $2 \mathrm{~d}$ ) The competent authority shall present in the form of a written statement a proposal to change the purpose of perpetual usufruct and set a deadline for the perpetual usufructuary to take a written position, not shorter than 2 months from the date of receipt of the proposal. If the perpetual usufructuary does not agree with the proposed change of the purpose of perpetual usufruct or has not presented a position, the competent authority may bring an action before a common court having jurisdiction over the location of the real estate. 2e) If the perpetual usufructuary submits the application referred to in paragraph 2 or $2 \mathrm{~b}$, the competent authority shall present a written position within 2 months of receipt of such application. If the authority does not agree to the change of the purpose of perpetual usufruct or does not present a position, the perpetual usufructuary may bring an action before a common court having jurisdiction over the location of the real estate.

This provision is not a classic example of an action against an administrative decision, but a right of action, by the claimant, against an administrative authority activity.

As regards an application submitted by a competent authority, in accordance with Article $73(2 \mathrm{~d})$ of the Real Estate Management Act, such authority shall present a proposal to change the purpose of perpetual usufruct in a written statement and set a deadline for the perpetual usufructuary to take a written position, which shall not be shorter than 2 months from the date of receipt of the proposal. If the perpetual usufructuary does not agree with the proposed change of the purpose of perpetual usufruct or does not present a position, the competent authority may bring an action before a common court having jurisdiction over the location of the real estate. It should be assumed that such an action may concern both an amendment of the agreement with respect to the purpose for which the real estate is given over for perpetual usufruct (and thus, as a consequence of a change in the interest rate), and possibly it may concern the termination of the agreement for perpetual usufruct of the real estate. In the light of paragraph 2e of Article 73 of the Real Estate Management Act, added on 15 August 2019, in the event of submission by the perpetual usufructuary of 
the application referred to in Article 73 paragraph 2 or $2 \mathrm{~b}$ of the Real Estate Management Act, the competent authority shall present a written position within 2 months of receipt of the application. If the authority does not agree for a change of the purpose of perpetual usufruct or has not presented a position, the perpetual usufructuary may bring an action before a common court having jurisdiction over the location of the real property. ${ }^{35}$

In conclusion, it should be stated that the common courts, when hearing actions against administrative decisions, have the competence to take evidence and the right to assess the evidence gathered in administrative proceedings ended with an administrative decision, e.g. expert opinions, witness statements, etc. Proceedings before the court triggered by the claim end with a judgment against which an appeal is possible. The specificity of a civil proceeding does not differ significantly from a typical trial before a common court, with the proviso that evidence gathered in administrative proceedings may be subject to judicial review. On the other hand, a common court is not allowed to interfere in the administrative decision in the course of proceedings brought by a claim in a case which has ended with an administrative decision. The Court is not allowed to apply reform or even cassation powers due to a lack of statutory authority. This is an important feature distinguishing the control of public administration exercised by common courts, as appeal bodies against administrative decisions, and as appointed to hear actions in relation to administrative decisions. Common courts e.g. the social security courts, as appeal bodies against decisions of public administration authorities in pension matters, have reform and cassation competences.

An action against an administrative decision is not an appeal for lack of subject matter of objection, i.e., an administrative decision. The action is linked to the administrative matter by the identity of the parties to the proceedings and evidence gathered in the administrative proceedings. This evidence should be assessed by the court in the course of the proceedings. However, the court may also admit, within the scope of the parties' and the court's powers, other evidence.

Another feature that distinguishes proceedings before common courts, as appeal bodies against administrative decisions, from trials against administrative decisions is the participation in the first proceedings, as a party, of the public administration body issuing the decision and the right to take account of an appeal lodged by a dissatisfied party against the body issuing the decision and, consequently, its amendment. In proceedings on actions against administrative decisions, the public administration body issuing the decision is not a party to the court proceedings, due to the statutory prohibition of appeal against such decisions. However, the outcome of the proceedings (the judgment), particularly if it is different and contrary to the administrative decision, will not be without significance for the administrative authority.

Finally, there is another issue, namely the relationship between the administrative decision and the claim brought as well as the relationship between the administrative decision and the judgment (final judgment). Two situations can be distinguished here. The first

35 E. Bończak-Kucharczyk, Article 73, in: Ustawa o gospodarce nieruchomościami. Komentarz aktualizowany, LEX Legal Information System, https://sip.lex.pl/\#/commentary/587724878/625447. Accessed 22.07.2020. 
situation concerns the legislator's regulation that taking legal action does not suspend the execution of the decision. This is, for example, the case in Article 131(3) of the EPL. Taking legal action does not suspend execution of the decision referred to in paragraph 1. Against this background, there is competition between the judicial process and the right to enforce an administrative decision. On the one hand, as has already been pointed out, a common court cannot interfere in an administrative decision and, on the other hand, the outcome of the trial is uncertain and future and, consequently, binding on the parties. In practice, it may turn out that the decision will be enforced before the end of a civil trial. This issue would require clear clarification by the legislator. On the other hand, when a final judgment has been issued, it appears to replace an administrative decision which, once the court ruling has become final, no longer binds the parties and the authority, unless such decision has been already executed earlier. It may be necessary to issue a judgment of an administrative and legal nature with respect to the decision, e.g. to the extent that the court has made a final judgment on civil claims, the decision will expire ex lege or will become pointless and it will have to be declared invalid (Article $162 \$ 1$ point 1 of the CAP).

The second situation concerns cases where the Act "keeps silent" about the fate of a decision after an action has been brought, in particular "keeps silent" about whether or not this decision is enforceable. This situation seems to be even more complicated. It seems that different solutions can be considered here: 1) to the extent to which the civil court has made a final judgment on the claims, a declaration of termination of the administrative decision should be made pursuant to Article 162(1)(1) of the CAP, 2) the fate of the administrative decision should be taken by the court in civil proceedings after the final judgment on the claims, ${ }^{36} 3$ ) the legislator should in each case foresee the effect of termination of the decision ex lege.

Adopting a different concept would result in an administrative decision and a judgment in the same case. This seems to be unacceptable.

\section{Summary and conclusions}

Action in a case ended with an administrative decision is an exception to the principle of appeal against an administrative decision under the provisions of the CAP. On the basis of an analysis of normative acts of statutory rank, I conclude that the legal basis determining the right of a party to bring an action against a decision occurs occasionally. The legislator usually does not grant the right to bring an action against an administrative decision. In most cases, the right of action applies to decisions concerning compensation. I am thinking here of both positive decisions, setting the amount of compensation, and negative decisions, as well as the authority's failure to issue a decision. The subject of court proceedings triggered by an action may be both the questioning of the amount of compensation and the failure to grant it. 
From a procedural point of view, a decision against which there is no right of appeal to a higher instance within the meaning of the CAP, i.e., a final decision, terminates the administrative procedure. An action before a common court in a case which has ended with an administrative decision starts new proceedings. From the point of view of the party, however, it can be assumed that this is a continuation of the same procedure but carried out from the beginning by a different authority. It is not entirely understandable why a case involving civil law matters has been entrusted by the legislator to be resolved by public authorities. The issue of compensation is a typical civil matter in the substantive and legal sense. All the differences arising from these two branches of law, regardless of the procedural dimension, cause many difficulties and doubts in the course of these proceedings, especially at the junction between them. These problems lie both with the administrative authorities and the court and, more importantly, with the parties to the proceedings. I am critical of the power of public administration bodies to issue administrative decisions in relation to which an action is entitled to be brought. I believe that the legislator is involving public administration too much in matters of a civil law nature. This state of affairs creates uncertainty for parties to proceedings as well as authorities.

Given that the vast majority of the actions in a case ended with an administrative decision concern compensation, the issues of determining them should be governed solely by civil law, and not by administrative law - uniformly. The role of the administrative authorities should be definitely limited or completely eliminated. Although I am aware of the problems that may arise in carrying out such a task. I see such a solution in the long term.

Within the framework of the de lege ferenda proposals, the legislator should be urged to change the current legal situation by regulating administrative proceedings at the interface with (civil) court proceedings more precisely, so as to duly safeguard the interests of the parties to the proceedings and to remove uncertainty on the part of the authorities.

\section{Literature}

Bończak-Kucharczyk E., Ustawa o gospodarce nieruchomościami. Komentarz aktualizowany, System Informacji Prawnej LEX, https://sip.lex.pl/\#/commentary/587724878/625447. Accessed 22.07.2020.

Borkowski J., Adamiak B., Postępowanie administracyjne i sqdowoadministracyjne, Warszawa 2019.

Gruszecki K., Prawo ochrony środowiska. Komentarz, 5th ed., Wolters Kluwer Polska, https://sip.lex. pl/\#/commentary/587291860/590794. Accessed 22.07.2020.

Jagielski J., Kontrola administracji publicznej, Warszawa 2006.

Litwin J., Problematyka sądownictwa administracyjnego, NP 1956, no. 1.

Łętowski J., Sądy powszechne i praworządność w administracji, Wrocław 1967.

Manowska M., Kodeks postępowania cywilnego. Komentarz, System Informacji Prawnej LEX, https:// sip.lex.pl/\#/commentary/587826880/624320. Accessed 19.07.2020.

Plucińska-Filipowicz A., Kosicki A., Ustawa o planowaniu i zagospodarowaniu przestrzennym. Komentarz aktualizowany, System Informacji Prawnej LEX, https://sip.lex.pl/\#/commentary/587754911/599324. Accessed 22.07.2020. 


\section{Legislative acts}

Act of 14 June 1960 Code of Administrative Procedure, Dz.U. (Journal of Laws) of 2020, item 256, as amended.

Act of 17 November 1964 Code of Civil Procedure, Dz.U. (Journal of Laws) of 2019, item 1460, as amended.

Act of 13 October 1995 Hunting Law, Dz.U. (Journal of Laws) of 2020, item 67, as amended.

Act of 2 April 1997 Constitution of the Republic of Poland, Dz.U. (Journal of Laws), no. 78, item 483, corrigendum: Dz.U. (Journal of Laws) of 2001, no. 28, item 319, as amended: Dz.U. (Journal of Laws) of 2006, no. 200, item 1471, Dz.U. (Journal of Laws), no. 114, item 946.

Act of 21 August 1997 Real Estate Management, Dz.U. (Journal of Laws) of 2020, item 65, as amended.

Act of 27 April 2001 Environmental Protection Law, Dz.U. (Journal of Laws) of 2020, item 1219, as amended.

Act of 30 August 2002 Law on Proceedings before Administrative Courts, Dz.U. (Journal of Laws) of 2019, item 2325, as amended.

Act of 27 March 2003 on Spatial Planning and Development, Dz.U. (Journal of Laws) of 2020, item 293, as amended.

Act of 29 June 2011 Preparing for and Performing Investments Involving Nuclear Power Facilities and Accompanying Investments, Dz.U. (Journal of Laws) of 2018, item 1537, as amended.

\section{Judicial decisions}

Judgment of the Voivodship Administrative Court in Warszawa of 29 October 2004, case file IV SA 2007/03, electronic version, LEX no. 164442.

Judgment of the Voivodship Administrative Court in Warszawa of 14 February 2012, case file I SA/ Wa 2369/11, LEX no. 1121563.

Judgment of the Voivodship Administrative Court in Białystok of 6 June 2013, case file I Aca 107/13, LEX no. 1335594.

Judgment of the Supreme Court of 18 November 2016, case file I CSK 759/15, electronic version.

Judgment of the Supreme Court of 10 August 2017, case file I CSK 30/17, electronic version, LEX no. 2352155.

Judgment of the Supreme Court of 27 February 2019, case file I NSK 17/18, electronic version, LEX no. 2643232.

Judgment of the Supreme Court of 19 June 2019, case file II CSK 288/18, electronic version, LEX no. 2684159.

Judgment of the Voivodship Administrative Court in Gdańsk of 26 September 2019, case file II SA/ Gd 234/19, electronic version, LEX no. 2726395.

Judgment of the Supreme Court of 9 October 2019, case file I NSK 59/18, electronic version, LEX no. 2729332.

Judgment of the Supreme Administrative Court of 28 January 2020, case file II OSK 689/18, electronic version, LEX no. 2798771.

Resolution of the Supreme Court (7z) of 23.11.1959, case file I CO 20/59, OSNCK 1960, no. 2, item 32.

Resolution of the Supreme Court of 9 October 2007, case file III CZP 46/07, electronic version, LEX no. 298665. 
Resolution of the Supreme Court of 11 October 2012, case file III CZP 49/12, OSNC 2013/3, item 32. Resolution of the Voivodship Administrative Court in Gdańsk of 30 December 2019, case file III SA/ Gd 789/19, electronic version, LEX no. 2759896.

Resolution of the Voivodship Administrative Court in Szczecin of 18 February 2020, case file II Sa/ Sz 52/20, electronic version, LEX no. 2783924.

Resolution of the Voivodship Administrative Court in Białystok of 12 March 2020, case file II SA/Bk 157/20, electronic version, LEX no. 2830010.

Ruling of the Supreme Administrative Court of 10 April 2008, case file I OSK 875/07, LEX no. 505244. 